\title{
PENERAPAN MODEL PEMBELAJARAN KOOPERATIF TIPE TWO STAY \\ TWO STRAY (TSTS) TERHADAP PEMAHAMAN KONSEP MATEMATIS SISWA PADA MATERI PERBANDINGAN KELAS VII SMP
}

\section{THE APPLICATION OF THE TWO STAY TWO STRAY (TSTS) COOPERATIVE LEARNING MODEL TO THE UNDERSTANDING OF STUDENT MATHEMATICS CONCEPTS IN COMPARISON MATERIALS OF MIDDLE SCHOOL CLASS VII.}

\author{
Sefrinal 1), Melia Roza ${ }^{2)^{*}}$ \\ ${ }^{1)}$ Dosen Prodi Matematika STKIP Pesisir Selatan \\ ${ }^{2)}$ Dosen Prodi Matematika STKIP Ahlussunnah Bukittinggi \\ *meliaroza28@gmail.com
}

\begin{abstract}
The process of learning mathematics in public middle school 2 Sutera students have not been fully involved actively during the learning process, so that the understanding of mathematical concepts of students is not good. Efforts that can be done apply cooperative learning model type Two Stay Two Stray (TSTS). The purpose of research is to know whether the understanding of mathematical concepts of students using cooperative learning model type Two Stay Two Stray (TSTS) is better than the understanding of mathematical concepts of students using conventional learning model on the matery ratio of public middle school 2 sutera class VII. This research was conducted on date 13 january 2020 to 14 february 2020 The data collection in this study used a test in the form of essays that tested the students' understanding of mathematical concepts. From the results of the study can be concluded that students' mathematical concept understanding using cooperative learning model type Two Stay Two Stray (TSTS) is better than conventional.
\end{abstract}

Keywords: Two Stay Two Stray (TSTS); Understanding of Mathematical Concepts.

\begin{abstract}
ABSTRAK
Proses pembelajaran matematika di siswa SMP Negeri 2 Sutera belum sepenuhnya terlibat secara aktif selama proses pembelajaran, sehingga pemahaman konsep matematis siswa kurang baik. Upaya yang dapat dilakukan menerapkan model pembelajaran kooperatif tipe Two Stay Two Stray (TSTS). Penelitian bertujuan mengetahui apakah pemahaman konsep matematis siswa menggunakan model pembelajaran kooperatif tipe Two Stay Two Stray (TSTS) lebih baik daripada pemahaman konsep matematis siswa menggunakan model pembelajaran konvensional pada materi perbandingan SMP Negeri 2 Sutera kelas VII. Penelitian ini dilakukan pada tanggal 13 Januari 2020 sampai 14 Februari 2020 dengan menggunakan metode Kuantitatif, pengumpulan data dalam penelitian ini menggunakan tes berupa soal essay yang menguji pemahaman konsep matematis siswa. Dari hasil penelitian dapat disimpulkan bahwa pemahaman konsep matematis siswa dengan menggunakan model pembelajaran kooperatif tipe Two Stay Two Stray (TSTS) lebih baik daripada model pembelajaran konvensional.
\end{abstract}

Kata kunci: Two Stay Two Stray (TSTS); Pemahaman Konsep Matematis. 


\section{PENDAHULUAN}

Pendidikan merupakan suatu kegiatan yang sangat penting dalam kehidupan manusia, karena dimanapun dan kapanpun di dunia terdapat pendidikan. Pendidikan adalah usaha sadar dan terencana untuk mewujudkan suasana belajar dan proses pembelajaran agar peserta didik secara aktif mengembangkan potensi dirinya untuk memiliki kekuatan spiritual, keagamaan, pengendalian diri, kepribadian, kecerdasan, akhlak mulia, serta keterampilan yang diperlukan dirinya, masyarakat, bangsa dan negara.

Matematika adalah mata pelajaran yang memegang peranan penting dalam kehidupan, karena dalam menjalani hidup ini tidak bisa lepas dari matematika dan banyak cabang ilmu lain yang memanfaatkan matematika. Tetapi, pada kenyataannya matematika masih dianggap sebagai mata pelajaran yang tidak disenangi, sulit, membingungkan, dan penuh dengan angka-angka. Hal ini menjadikan matematika sebagai pelajaran yang membosankan sehingga siswa banyak yang merasa pesimis dalam belajar matematika.

Berdasarkan pengamatan (observasi) yang peneliti lakukan di SMP Negeri 2 Sutera, pembelajaran yang dilakukan masih terpusat pada guru. Dilihat dari proses pembelajaran yang berlangsung di kelas, siswa belum sepenuhnya terlibat secara aktif selama proses pembelajaran. Siswa masih kurang paham tentang konsep materi yang disampaikan guru. Hal ini dapat dilihat rendahnya hasil belajar matematika siswa semester 1 tahun pelajaran $2019 / 2020$.

Model pembelajaran kooperatif merupakan model pembelajaran dengan menggunakan sistem pengelompokan/tim kecil, yaitu antara empat sampai enam orang yang mempunyai latar belakang kemampuan akademik, jenis kelamin, ras, atau suku yang berbeda (heterogen). Dan salah satu model pembelajaran kooperatif adalah model pembelajaran kooperatif tipe Two Stay Two Stray (TSTS). Menurut Lie dalam Shoimin (2016:222) menyatakan "Model pembelajaran tipe Two Stay Two Stray merupakan model pembelajaran yang memberi kesempatan kepada kelompok untuk membagikan hasil dan informasi dengan kelompok lainnya". Berdasarkan uraian di atas dapat disimpulkan bahwa model pembelajaran tipe Two Stay Two Stray merupakan model pembelajaran yang memberikan kesempatan kepada kelompok untuk berbagi pengetahuan dan pengalaman dengan kelompok lain.

Tahap pembelajaran kooperatif model TSTS menurut Shoimin (2016:223-225) adalah sebagai berikut. 
a) Persiapan

Pada tahap persiapan ini, hal yang dilakukan guru adalah membuat silabus dan sistem penilaian, desain pembelajaran, menyiapkan tugas siswa dan membagi siswa menjadi beberapa kelompok dengan masing-masing anggota 4 siswa dan setiap anggota kelompok harus heterogen berdasarkan prestasi akademik siswa dan suku.

b) Presentasi Guru

Pada tahap ini guru menyampaikan indikator pembelajaran, mengenal dan menjelaskan materi sesuai dengan rencana pembelajaran yang telah dibuat.

c) Kegiatan Kelompok

Pada kegiatan ini pembelajaran menggunakan lembar kegiatan yang berisi tugas-tugas yang harus dipelajari oleh tiap-tiap siswa dalam satu kelompok. Setelah menerima lembar kegiatan yang berisi permasalahan-permasalahan yang berkaitan dengan konsep materi dan klasifikasinya, siswa mempelajarinya dalam kelompok kecil (4 siswa) yaitu mendiskusikan masalah tersebut bersama-sama anggota kelompoknya.

d) Formalisasi

Setelah belajar dalam kelompok dan menyelesaikan permasalahan yang diberikan salah satu kelompok mempresentasikan hasil diskusi kelompoknya untuk dikomunikasikan atau didiskusikan dengan kelompok lainnya. Kemudian guru membahas dan mengarahkan siswa ke bentuk formal.

e) Evaluasi Kelompok dan PenghargaanPada tahap evaluasi ini untuk mengetahui seberapa besar kemampuan siswa dalam memahami materi yang telah diperoleh dengan menggunakan model pembelajaran kooperatif model TSTS. Masing-masing siswa diberi kuis yang berisi pertanyaan-pertanyaan dari hasil pembelajaran dengan model TSTS, yang selanjutnya dilanjutkan dengan pemberian penghargaan kepada kelompok yang mendapatkan skor rata-rata tertinggi.

Berdasarkan Tahap pembelajaran Two Stay Two Stray (TSTS) ini adalah untuk membuat siswa lebih memahami konsep yang digunakan dalam proses pembelajaran matematika. Hal ini dikarenakan langkah - langkah atau tahapan dalam model pembelajaran ini yaitu siswa dituntut untuk berdiskusi dengan teman sekelompoknya dalam mengerjakan lembar kegiatan siswa yang berkaitan dengan konsep materi dan klasifikasinya. Kemudian siswa harus dapat memahami konsep atau ide-ide matematis yang diperoleh dalam diskusi kelompok, karena dua orang siswa yang tinggal dalam 
kelompok bertugas membagikan hasil kerja kelompok dan informasi mereka ketamu mereka. Sehingga siswa mampu menyatakan konsep dan mengekpresikan solusi matematis secara tertulis, lisan maupun bentuk visual lainnya.

Pemahaman konsep merupakan tujuan utama dari pembelajaraan matematika. Hal ini sesuai dengan salah satu tujuan pembelajaraan matematika yang terdapat dalam Permendiknas No. 22 Tahun 2006 yaitu "Siswa mampu memahami konsep matematika, menjelaskan keterkaitan antar konsep dan mengaplikasikan konsep atau algoritma secara luwes, akurat, efisien, dan tepat dalam pemecahan masalah".

Peningkatan pemahaman konsep matematis siswa dapat diukur dengan indikatorindikator pemahaman konsep. Menurut Bloom dalam Sumarmo (2014:20) "Secara umum indikator memahami matematis meliputi: mengenal dan menerapkan konsep, prosedur, prinsip dan idea matematis".

Adapun menurut NCTM dalam Munggaranti (2007:25) menyatakan bahwa, pemahaman siswa terhadap konsep matematis dapat dilihat dari kemampuan siswa sebagai berikut yaitu 1) Mendefinisikan konsepecara verbal dan tulisan, 2) Membuat contoh dan non contoh penyangkal, 3) Mempresentasikan suatu konsep dengan model, diagram, dan simbol, 4) Mengubah suatu bentuk representasi ke bentuk yang lain, 5) Mengenal berbagai makna dan interprestasi konsep, 6) Mengidentifikasi sifat-sifat suatu konsep dan mengenal syarat-syarat yang menentukan suatu konsep, 7) Membandingkan dan membedakan konsep- konsep.

Dijelaskan juga pada dokumen Peraturan Dirjen Dikdasmen Nomor 506/C/Kep/PP/2004 (dalam Shadiq, 2009:13), bahwa pemahaman konsep merupakan kompetensi yang ditunjukkan siswa dalam memahami konsep dan dalam melakukan prosedur (algoritma) secara luwes, akurat, efisien, dan tepat. Indikator-indikator dari pemahaman konsep matematis tersebut adalah sebagai berikut: 1) Menyatakan ulang sebuah konsep, 2) Mengklasifikasikan objek menurut sifat-sifat tertentu sesuai konsepnya, 3) Memberi contoh dan non contoh dari konsep, 4) Menyajikan konsep dalam berbagai representasi matematis, 5) Mengembangkan syarat perlu atau syarat cukup dari suatu konsep, 6) Mengaplikasikan konsep atau algoritma dalam pemecahan masalah.

Berdasarkan indikator-indikator yang dikemukakan oleh para ahli di atas, maka indikator yang akan peneliti gunakan pada penelitian ini adalah sebagai berikut: 1) Menyatakan ulang sebuah konsep, 2) Mengklasifikasikan objek menurut sifat-sifat 
tertentu sesuai konsepnya, 3) Memberikan contoh dan non contoh dari konsep, 4) Menyajikan konsep dalam berbagai representasi matematis, 7) Mengaplikasikan konsep atau algoritma dalam pemecahan masalah.

Berdasarkan masalah di atas, maka permasalahan yang akan dirumuskan adalah “Apakah pemahaman konsep matematis siswa menggunakan model pembelajaran kooperatif tipe Two Stay Two Stray (TSTS) lebih baik daripada pemahaman konsep matematis siswa menggunakan model pembelajaran konvensional?". Sehubungan dengan rumusan masalah tersebut maka tujuan penelitian ini adalah "untuk mengetahui apakah pemahaman konsep matematis siswa menggunakan model pembelajaran kooperatif tipe Two Stay Two Stray (TSTS) lebih baik daripada pemahaman konsep matematis siswa menggunakan model pembelajaran konvensional".

Sesuai dengan kajian teori dan rumusan masalah di atas maka peneliti mengemukakan hipotesis penelitian ini adalah Pemahaman konsep matematis siswa menggunakan model pembelajaran kooperatif tipe Two Stay Two Stray (TSTS) lebih baik daripada pemahaman konsep matematis siswa menggunakan model pembelajaran konvensional.

\section{METODOLOGI}

\subsection{Jenis Penelitian}

Jenis penelitian ini adalah penelitian eksperimen dengan rancangan penelitiannya Randomized Control Group Only Design Sesuai dengan jenis penelitian tersebut, maka peneliti menggunakan dua kelas sampel, yaitu kelas eksperimen dan kelas kontrol. Adapun perlakuan yang diberikan pada kelas eksperimen adalah menggunakan model pembelajaran kooperatif tipe Two Stay Two Stray (TSTS) dan kelas kontrol merupakan kelas yang menerapkan pembelajaran konvensional. Hal yan dibandingkan dalam penelitian ini adalah pemahaman konsep matematis siswa.

Rancangan penelitian ini adalah Randomized Subjects Posttest Only Control Group Design.

\subsection{Populasi dan Sampel}

Populasi penelitian ini adalah seluruh siswa kelas VII SMP Negeri 2 Sutera dengan jumlah 137 orang siswa.Sampel penelitian diambil sebanyak dua kelas, satu untuk kelas 
eksperimen dan yang lainnya untuk kelas kontrol. Pengambilan sampel pada kelas ini menggunakan teknik random sampling.

Sampel dalam penelitian ini adalah kelas $\mathrm{VII}_{6}$ sebagai kelas eksperimen dan kelas $\mathrm{VII}_{5}$ sebagai kelas kontrol.

Variabel dalam penelitian ini adalah variabel bebas dan variabel terikat. Variabel bebasnya adalah pembelajaran menggunakan model pembelajaran kooperatif tipe Two Stay Two Stray (TSTS) pada kelas eksperimen dan model pembelajaran konvensional pada kelas kontrol. Dan variabel terikat dalam penelitian ini adalah pemahaman konsep matematis siswa.

Instrumen yang digunakan dalam penelitian ini adalah tes pemahaman konsep matematis siswa yang terdiri dari 10 item soal dalam bentuk soal essay yang memuat indikator pemahaman konsep matematis. Tes dikatakan valid apabila soal telah dapat mengukur apa yang seharusnya diukur sehingga dapat digunakan atau dipakai.

Analisis soal juga dilakukan pada tes akhir yaitu tes pemahaman konsep. Selanjutnya melakukan uji statistik yang digunakan untuk menguji hipotesis adalah uji statistik parametrik. Sebelum melakukan uji hipotesis, terlebih dahulu dilakukan uji normalitas dan uji homogenitas. Uji statistik yang digunakan adalah uji t.

\section{HASIL DAN PEMBAHASAN}

\subsection{Hasil}

Hasil tes pemahaman konsep matematis siswa dapat dilihat pada Tabel 2

Tabel 1 Hasil tes pemahaman konsep matematis siswa

\begin{tabular}{lccccccc}
\hline No & Kelas & N & Skor Max & Skor Min & $\bar{X}$ & $\mathbf{S}^{2}$ & S \\
\hline 1 & Eksp & 23 & 28 & 13 & 19.6 & 31 & 5.5 \\
2 & Kontrol & 23 & 25 & 7 & 15.9 & 32 & 5.6 \\
\hline
\end{tabular}

Sumber: Hasil Pengolahan Data, 2020

Berdasarkan Tabel 1, dapat dilihat bahwa rata-rata skor siswa kelas eksperimen lebih tinggi daripada kelas kontrol. Selain itu, jika kita lihat dari variansi dan simpangan bakunya juga memiliki perbedaan dimana variansi dan simpangan baku kelas eksperimen lebih rendah daripada kelas kontrol. Rendahnya simpangan baku pada kelas eksperimen ini dapat diartikan bahwa skor siswa menyebar mendekati rata-rata daripada kelas kontrol, 
artinya bahwa kelas tersebut terdapat siswa yang memiliki kemampuan tinggi, siswa yang berkemampuan sedang, dan siswa yang berkemampuan rendah.

Pembuktian hipotesis dilakukan uji normalitas terhadap data hasil tes akhir pemahaman konsep matematika siswa diperoleh bahwa kelas eksperimen dan kelas kontrol berdistribusi normal. Sedangkan setelah dilakukam uji homogenitas variansi data tes pemahaman konsep matematis siswa dapat disimpulkan bahwa variansi homogen.

Syarat untuk uji hipotesis dengan menggunakan uji-t sudah terpenuhi, yaitu data harus berdistribusi normal dan variansi homogen. Berdasarkan perhitungan uji-t diperoleh $t_{\text {hitung }}$ $=2,246$ dan $t_{\text {tabel }}=1,678$. Berdasarkan kriteria penghitungan bahwa $t_{\text {hitung }}>t_{\text {tabel }}$ dapat disimpulkan bahwa hipotesis diterima, bahwa pemahaman konsep matematika siswa dengan penerapan model pembelajaran kooperatif tipe Two Stay Two Stray (TSTS) lebih baik daripada pemahaman konsep matematis siswa dengan pembelajaran konvensional.

\subsection{Pembahasan}

Berdasarkan hasil deskripsi dan analisis data yang dilakukan, dapat disimpulkan bahwa pemahaman konsep matematis siswa yang menggunakan model pembelajaran kooperatif tipe Two Stay Two Stray (TSTS) lebih baik daripada pemahaman konsep matematis siswa yang menggunakan pembelajaran konvensional. Hal ini tampak pada rata-rata skor tes akhir kelas eksperimen lebih tinggi daripada kelas kontrol tentu ditunjang oleh penerapan model pembelajaran TSTS dan LKS sedangkan kelas kontrol dengan pembelajaran konvensional yaitu pendekatan saintifik.

Tingginya rata-rata skor kelas eksperimen daripada kelas kontrol, hal ini disebabkan pada kelas eksperimen siswa lebih bersemangat dan aktif dalam belajar dibandingkan kelas kontrol. Model pembelajaran Two Stay Two Stray (TSTS) memungkinkan siswa belajar dalam kelompok sehingga dapat membantu siswa mendapatkan pengetahuan, keterampilan, dan sikap secara aktif. Siswa diminta untuk berbagi ide dalam kelompok dan menyelesaikan persoalan secara bersama sehingga siswa saling berbagi pengetahuan dalam kelompok. Pemahaman konsep matematis siswa dapat dilatih ketika siswa bertamu ke kelompok lain memberikan kesempatan kepada siswa untuk memperoleh bantuan dari temannya dalam memahami permasalahan, membandingkan, ataupun menguatkan pengertian yang telah dimiliki dari hasil diskusi dalam kelompoknya.dengan begitu siswa dapat mengevaluasi sendiri, seberapa tepatkah pola pikirnya terhadap suatu konsep dengan pola pikir nara sumber. Dengan lebih banyaknya sumbangan-sumbangan 
pemikiran dari teman-temannya di kelas, hal ini dapat membantu siswa untuk lebih memahami materi yang sedang dipelajari. Hal ini didukung oleh penelitian yang dilakukan oleh Mimi Handayani (2014) dengan judul "Pengaruh Model Pembelajaran Kooperatif Tipe Two Stay Two Stray Terhadap Pemahaman Konsep Matematis Siswa Kelas VIII SMP Negeri 13 Padang” yang mengatakan bahwa nilai rata-rata tes akhir kelas eksperimen lebih tinggi dibandingkan nilai rata-rata tes akhir kelas kontrol.

Dan Penelitian Cahya Dwi Budiarti, dkk (2019) dengan judul "Kontribusi model Pembelajaran M APOS Terhadap Pemahaman Konsep Matematis Siswa dengan hasil penelitian Eksperimen lebih tinggi dari pada kelas lontrol.

Selain itu, dalam pembelajaran dengan menggunakan model Two Stay Two Stray (TSTS) siswa bekerja di dalam kelompoknya untuk menemukan sendiri konsep yang dipelajari kemudian menjelaskan konsep yang diperoleh dan mempertanggungjawabkannya dalam diskusi kelas. Dalam diskusi kelas, guru membantu siswa menemukan konsep yang benar dan memperbaiki kemungkinan salah konsep pada siswa. Di kelas kontrol, guru memberikan konsep kepada siswa secara langsung sehingga siswa hanya menghafal konsep dari suatu materi yang diberikan. Selanjutnya, siswa diberi kesempatan memahami materi lebih lanjut dengan mengerjakan beberapa soal latihan.

Secara hipotesis pemahaman konsep matematis kelas ekperimen lebih baik daripada pemahaman konsep matematis kelas kontrol. Namun pada pelaksanaannya masih terdapat beberapa kendala selama peneliti menerapkan model pembelajaran kooperatif tipe Two Stay Two Stray (TSTS). Dimana pembelajaran TSTS memerlukan waktu yang cukup lama yaitu pada tahap mengerjakan LKS, bertamu, dan menerima tamu. Solusinya, peneliti terus mengingatkan waktu kepada siswa ketika mengerjakan LKS, berdiskusi, membagi hasil diskusi ke kelompok lain, dan menyajikan hasil diskusi, sehingga waktu yang digunakan tidak melebihi seperti yang telah direncanakan. Dan pada saat bertamu, siswa cenderung lebih banyak bercanda dan tidak membahas. Solusinya peneliti memberi peringatan kalau siswa yang bertamu itu harus membahas tentang latihan yang sudah dikerjakan saja bukan membahas hal yang lain. Dalam pembelajaran TSTS ini kegiatan kelompok siswa seharusnya beranggota 4 orang dalam satu kelompok, akan tetapi jumlah siswa ada yang beranggotakan 5 orang dalam satu kelompok karna jumlah siswa dalam satu kelas itu ganjil. Solusinya kelompok yang beranggota 5 orang siswa, siswa yang bertamu tetap 2 orang dan yang tinggal 3 orang. Namun secara keseluruhan rata-rata 
pencapaian indikator pemahaman konsep pada kelas eksperimen lebih tinggi daripada rata-rata pencapaian indikator pada kelas kontrol. Sehingga dapat dikatakan pemahaman konsep matematis siswa yang menggunakan model pembelajaran kooperatif tipe Two Stay Two Stray (TSTS) lebih baik daripada pemahaman konsep matematis siswa yang menggunakan pembelajaran konvensional.

Pencapaian indikator pemahaman konsep matematis siswa pada soal tes akhir mewakili 5 indikator yang ada. Pada indikator 1 yaitu menyatakan ulang sebuah konsep yang mewakili soal 6 dan 8, perbedaan yang cukup besar antara rata-rata pada kelas eksperimen dan kelas kontrol. Hal ini disebabkan karena sebagian jawaban tes akhir siswa kelas eksperimen sudah tepat dan lengkap dalam menyatakan ulang sebuah konsep. Sedangkan sebagian besar kelas kontrol menunjukkan pemahaman yang masih kurang terhadap konsep yang dinyatakan. Seperti soal no 6, siswa mengalami kesulitan dalam mendaftarkan anggota dari kelipatan 2 dan faktor dari 8 . Hal ini juga terjadi pada soal no 8 , siswa masih bingung dan lupa tentang komplemen dari suatu himpunan.

Indikator 2 yaitu mengklasifikasikan objek menurut sifat-sifat tertentu sesuai konsepnya yang mewakili soal no 2 dan 4, perolehan nilai rata-rata kelas eksperimen lebih tinggi daripada kelas kontrol. Hal ini disebabkan pada kelas eksperimen dengan menggunakan model TSTS dan LKS, siswa terlatih berbagi ide dalam kelompok dan menyelesaikan persoalan secara bersama sehingga siswa saling berbagi pengetahuan dalam kelompok. Sebagian besar jawaban tes akhir siswa kelas eksperimen sudah dapat mengklasifikasikan objek menurut sifat-sifat tertentu sesuai konsepnya sesuai dengan benar dan lengkap. Sedangkan pada siswa kelas kontrol bisa mengklasifikasikan objek menurut sifat-sifat tertentu sesuai konsepnya namun masih banyak kesalahan. Seperti pada soal no 2 siswa terlihat masih banyak kesalahan dalam menyatakan himpunan $P=$ $\{2,3,5,7,11\}$, kebanyakan siswa membuat $\mathrm{P}$ adalah himpunan bilangan ganjil, bilangan asli, dan bilangan genap. Siswa sulit membedakan antara bilangan asli, bilangan genap, bilangan ganjil, dan bilangan prima.

Indikator 3 yaitu memberikan contoh dan non contoh yang mewakili soal no 1 dan 3 , perolehan nilai rata-rata kelas eksperimen lebih tinggi daripada kelas kontrol. Hal ini disebabkan pada kelas eksperimen dengan menggunakan model TSTS dan LKS, siswa terlatih berbagi ide dalam menyampaikan ide-ide mereka saat berdiskusi, saling bertanya jawab dan kemudian menjelaskan melalui gambar. 
Indikator 4 yaitu menyajikan konsep dalam berbagai bentuk representasikan matematis yang mewakili soal no 5 dan 7, sebagian besar kelas eksperimen sudah menunjukkan kemampuan menyajikan konsep dalam berbagai bentuk representasikan matematis, begitu pula pada kelas kontrol. Namun kemampuan kelas eksperimen lebih baik daripada kelas kontol. Dimana sebagian jawaban tes akhir siswa kelas eksperimen sudah tepat dan lengkap dalam menyajikan konsep dalam berbagai bentuk representasikan matematis. Sedangkan sebagian besar kelas kontrol menunjukkan pemahaman yang masih kurang terhadap konsep yang disajikan.

Indikator 5 yaitu mengaplikasikan konsep atau algoritma dalam pemecahan masalah yang mewakili soal no 9 dan 10, kemampuan kelas eksperimen dalam mengaplikasikan konsep atau algoritma dalam pemecahan masalah lebih baik daripada kelas kontrol. Sebagian jawaban siswa kelas eksperimen sudah benar dalam mengaplikasikan konsep atau algoritma dalam pemecahan masalah. Sedangkan siswa kelas kontrol banyak kesalahan dalam mengaplikasikan konsep atau algoritma dalam pemecahan. Hal ini disebabkan siswa pada kelas eksperimen sudah dibiasakan untuk menyelesaikan masalah dengan rinci. Melalui model pembelajaran TSTS dan LKS siswa terbiasa untuk mengeluarkan ide-ide dalam menyelesaikan masalah terhadap materi yang dipelajari dengan baik. Proses pembelajaran yang terjadi pada kelas kontrol yaitu siswa tidak terbiasa berbagi dan membandingkan ide-ide mereka dengan siswa lain. Selama proses pembelajaran siswa cenderung mengerjakan sendiri dan lebih banyak menerima penjelasan yang diberikan guru. Siswa terbiasa mengerjakan soal dengan meniru langkah-langkah penyelesaian soal sehingga kemampuan dalam soal mengaplikasikan konsep atau algoritma dalam pemecahan masalah belum berkembang yang berdampak pada sulitnya siswa dalam menyelesaikan suatu permasalahan. Berdasarkan uraian di atas dapat kita simpulkan bahwa setiap jawaban tes akhir siswa dalam pencapaian indikator pemahaman konsep matematis siswa, siswa kelas eksperimen lebih tinggi daripada kelas kontrol.

\section{SIMPULAN}

Berdasarkan hasil penelitian dan analisis yang telah dilakukan, dapat diambil kesimpulan bahwa pemahaman konsep matematis siswa dalam penerapan model 
pembelajaran kooperatif tipe Two Stay Two Stray (TSTS) lebih baik daripada pemahaman konsep matematis siswa menggunakan model pembelajaran konvensional.

Kekurangan model pembelajaran kooperatif tipe Two Stay Two Stray (TSTS) adalah membutuhkan waktu yang lama, siswa yang tidak terbiasa belajar kelompok merasa asing dan sulit untuk bekerjasama sehingga siswa cenderung tidak mau belajar dalam kelompok.

Semoga penelitian ini dapat menjadi acuan bagi guru dalam menerapkan model pembelajara tipe Two Stay Two Stray (TSTS) di sekolah dan menjadi referensi untuk penelitian berikutnya.

\section{DAFTAR PUSTAKA}

Handayani, Mimi. 2014. Pengaruh Model Pembelajaran Kooperatif Tipe Two Stay Two Stray (TSTS) Terhadap Pemahaman Konsep Matematis Siswa Kelas VIII SMP Negeri 13 Padang. Jurnal Pendidikan Matematika. Vol 3 No 1. Hal 56-60.

Shadiq, Fadjar. 2009. Kemahiran Matematika. Ypgyakarta: Departemen Pendidikan Nasional.

Shoimin, Aris. 2016. 68 Model Pembelajaran Inovatif dalam Kurikulum 2013. Yogyakarta: AR-RUZZ.MEDIA.

UPI.

Sumarmo, Utari. 2014. Berpikir Disposisi Matematik Serta Pembelajarannya. Bandung: UPI. 